\title{
Corrosion Resistance of as-rolled Mg-Li-AlSi Alloys
}

\author{
Zilong Zhao ${ }^{1,2}$, Yiding, Liu ${ }^{1,2}$, Yifeng Zhong ${ }^{1,2^{*}}$, Xianhua Chen ${ }^{3}$, Zhiqiang Zhang ${ }^{4}$ \\ ${ }^{1}$ School of Civil Engineering, Chongqing University, Chongqing 400045, China \\ ${ }^{2}$ Key Laboratory of New Technology for Construction of Cities in Mountain Area (Chongqing \\ University), Ministry of Education, Chongqing 400045, China \\ ${ }^{3}$ College of Materials Science and Engineering, Chongqing University, Chongqing 400045, China \\ ${ }^{4}$ Key Lab of Electromagnetic Processing of Materials, Ministry of Education, Northeastern University, \\ 314Mailbox, Shenyang 110819, China \\ *E-mail: $\underline{529972463 @ q q . c o m}$
}

doi: $10.20964 / 2018.05 .16$

Received: 11 December 2017 / Accepted: 5 March 2018 / Published: 10 April 2018

In this paper, single $\alpha$-phase alloys (Mg-4Li, Mg-4Li-3AlSi) and single $\beta$-phase alloys $(\mathrm{Mg}-12 \mathrm{Li}, \mathrm{Mg}$ 12Li-3AlSi) were used as the research object. The corrosion behaviors of four alloys in $3.5 \mathrm{wt} \% \mathrm{NaCl}$ solution are investigated. The influence of elemental $\mathrm{Al}$ and $\mathrm{Si}$ on the corrosion resistance of the alloy is revealed. The corrosion resistances of $\alpha$-phase alloy $\mathrm{Mg}-4 \mathrm{Li}$ and $\mathrm{Mg}-4 \mathrm{Li}-3 \mathrm{AlSi}$ are obviously better than that of $\beta$-phase alloy Mg-12Li and Mg-12Li-3AlSi. The addition of Al-Si master alloy could increase the rate of hydrogen evolution and decrease the corrosion resistance of the alloy. The surface phase of the Mg-Li-AlSi is mainly consist of $\alpha-\mathrm{Mg}, \beta-\mathrm{Li}, \mathrm{Mg}(\mathrm{OH})_{2}, \mathrm{Al}_{2} \mathrm{O}_{3}$ and $\mathrm{Mg}_{2} \mathrm{Si}$.

Keywords: Al-Si eutectic, Mg-Li alloys, precipitation, corrosion, rolling

\section{$\underline{\text { FULL TEXT }}$}

(C) 2018 The Authors. Published by ESG (www.electrochemsci.org). This article is an open access article distributed under the terms and conditions of the Creative Commons Attribution license (http://creativecommons.org/licenses/by/4.0/). 